\title{
Contegra conduit for reconstruction of the right ventricular outflow tract: a review of published early and mid-time results Aristotle D Protopapas* and Thanos Athanasiou
}

\author{
Address: Department of Biosurgery and Surgical Technology, Imperial College London, St. Mary's Hospital, London, W2 1 NY, UK \\ Email: Aristotle D Protopapas* - aristotelis.protopapas02@imperial.ac.uk; Thanos Athanasiou - t.athanasiou@imperial.ac.uk \\ * Corresponding author
}

Published: 18 November 2008

Journal of Cardiothoracic Surgery 2008, 3:62 doi:10.1186/1749-8090-3-62
Received: I July 2008

Accepted: 18 November 2008

This article is available from: http://www.cardiothoracicsurgery.org/content/3/1/62

(c) 2008 Protopapas and Athanasiou; licensee BioMed Central Ltd.

This is an Open Access article distributed under the terms of the Creative Commons Attribution License (http://creativecommons.org/licenses/by/2.0), which permits unrestricted use, distribution, and reproduction in any medium, provided the original work is properly cited.

\begin{abstract}
Objective: The valved conduit Contegra (bovine jugular vein) has being implanted for more than 7 years in the right ventricular outflow tract and it is noted that the available reports have been mixed. The aim of this study is to review the reported evidence in the literature.

Methods: Search of the relevant literature for the primary endpoints of operative mortality and morbidity and secondary endpoints of follow-up haemodynamic performance including severe stenosis, regurgitation and need for reintervention are presented.

Results: We selected and analysed 17 series including 767 patients. Commonest indication was Fallot's tetralogy. Operative mortality was $2.6 \%$. Operative morbidity was $13.9 \%$. In follow-up, the incidence of intraconduit stenosis was $10.9 \%$ (incidence of stenosis for the 12 millimetre conduit was $83.3 \%$ in one series) and that of at least moderate regurgitation was $6.3 \%$.

The aspirin users had a stenosis incidence of $10.5 \%$ compared to the non-users had a stenosis incidence of $9.6 \%$.

Conclusion: A dissent on the performance of the Contegra is discussed, while results are satisfactory in the majority of studies apart for the smallest conduits (I2 and 14 millimetre), suggesting an association to compromised run-off. The role of aspirin as antithrombotic modulator remains controversial.
\end{abstract}

\section{Introduction}

The refinement of congenital cardiac surgical procedures requiring reconstruction of the right ventricular outflow tract (RVOT) (or substitution for the autograft pulmonary valve in Ross procedure) has led to an increased need for valved conduits, especially for neonates and small infants.

The haemodynamic performance and long-term complications of xenograft, composite grafts and homografts have been far from ideal. In view of the rising demand for conduits (especially of small internal diameter) and the decrease in homograft availability, alternative options have been sought.

A new solution popularised in Europe and of late in the USA and Canada is a valved conduit xenograft, the Contegra (formerly Venpro, Medtronic Inc, Minneapolis, MN, USA). Derived from bovine jugular vein, it incorporates the native tri-leaflet valve and a natural sinus. The prosthesis is preserved in buffered low concentration glutaraldehyde in order to maintain the leaflet flexibility. Contegra conduits are availble with internal diameter of 
$12,14,16,18,20$ and 22 millimeters (mm). Theoretical advantages include structural continuity and 'off-theshelf availability. An inherent feature of the Contegra is the fact that being derived from the venous circulation and has the morphological characteristics of a 'vascular' valved conduit under conditions of low pressure similar to the pulmonary vascular tree (and not the higher pressure and hemodynamic condition of the systemic circulation). Therefore its use is not licenced for the left ventricular outflow tract.

A number of studies have reported on this conduit. It appears that some surgeons are concerned with its performance, while others are satisfied. In order to draw some further practical conclusions, we have systematically reviewed the literature in order to assess the existing cumulative peri-operative data and postoperative performance.

\section{Methods}

Ethical issues were not raised, therefore ethical approval was not sought. No conflict of interest is declared.

We performed a literature search (PubMed) for studies reporting on Contegra, published between 1965 and 31 March 2007): Searching keyword was "Contegra" limited to "human subjects." Articles were also identified using the function "related articles" in PubMed and cross-validated by hand search. No language restrictions were applied.

We performed summary descriptive statistics on pooled data:Primary outcomes discussed were surgical mortality and morbidity and secondary outcomes as follow-up haemodynamic performance including: intra-conduit pressure difference recordings, severe conduit stenosis and regurgitation as also need for reintervention. Special care was given to include data on conduit specific reintervention incidence during the follow-up period. Postoperative aspirin strategy was also assessed. Denominators were related to actual data. Missing data were not defaulted. Where follow-up data were sought, we opted for a period prevalence denominator of patient-years and haemodynamic assessment was extracted focusing at the time point of measurement. Due to inherent heterogeneity we did not attempt statistical inference.

\section{Data and analysis}

We identified and considered 22 publications [1-22]. Five of them included data from others [2] from [13,3] from [14] and [15,6] from [16,11] from [19] with apparently overlapping cohorts, so we utilized data from the largest ones $[2,3,6,11]$.
Two papers from the same country $[2,6]$ presented equal number of subjects with partially overlapping periods of observation. The units where surgery took place were not stated in either. The rest of their data being dissimilar, we concluded that the two series had to be entered to the database separately and that the same number of patients appears plainly a coincidence.

Thus we accumulated data from 17 series $[1-12,17,18,21$ 23].

\section{Results}

\section{Demographics And Pathologies}

Data from 767 patients were reported in total in these 17 studies (ranging from 6 to 108 per study). Each patient received a single Contegra with the exception of two case that had two each $[1,20]$.

Mean age was 7.6 years (range 2 days-55 years). Mean weight was $23.1 \mathrm{Kg}$ (range $2.8-125 \mathrm{Kg}$ ). The commonest indications for implantation of Contegra was Fallot's Tetralogy (198 patients), Arterial Trunk (Truncus, 91 patients), Ross procedure (80 patients), Pulmonary Atresia (50 patients), Double Outlet/Inlet Right Ventricle (40 patients), Transposition of Great Arteries (29 patients).

\section{Operative Outcomes}

We sought the standardised surgical outcomes according to published guidelines[23].

Mortality

There were 20 deaths reported in 766 operations. The cumulative Mortality was thus $2.6 \%$.

Morbidity

Morbidity is presented in Table 1 . Morbidity data were individually and clearly reported in 8 series with 330 patients [[3-5,8,10-12] and [23]]: 46 patients suffered one or more of 54 complications. Cumulative operative morbidity was thus calculated to $13.9 \%$.

\section{Follow-Up}

584 patients had being followed up for 22 months in average (range 1-56) rending the total calculated followup to 573 patient-years.

Echocardiography was utilised for routine interval followup.

Severe Stenosis and timepoint of follow-up is presented in Table 2. 
Table I: Contegra ${ }^{\mathrm{TM}}$ 1999-2007-perioperative complications

\begin{tabular}{cc}
\hline Type & Number of incidents \\
\hline Bleeding & 5 \\
\hline Neurological & 3 \\
\hline Sepsis & 4 \\
\hline Respiratory & 13 \\
\hline Thrombosis & 2 \\
\hline Renal & 2 \\
\hline Cardiac & 13 \\
\hline Other & 12 \\
\hline Total & 54 \\
\hline
\end{tabular}

Average pressure differences (commonly yet erroneously [24] termed 'gradient') were: peak $17 \mathrm{~mm} \mathrm{Hg}$ (millimetres of Mercury) (range 8.5-27) and mean $8.2 \mathrm{mmHg}$ (range $7-13$ ). Incidence of intraconduit stenosis, was $10.9 \%$ necessitating 56 interventional and 28 surgical procedures.

Routine postoperative aspirin administration was explicitly stated in six series $[2,5,9,17,21,22]$. The authors of another series [4] reported adding post discharge aspirin empirically in neonates $(10 \mathrm{mg} /$ day till the patient reaches $5-6 \mathrm{Kg}$ of body weight) after two thrombotic events in their cohort. Routine aspirin administration is not mentioned in the other series.

The aspirin users had a stenosis incidence of $10.5 \%$. The non-users had a stenosis incidence of $9.6 \%$.

Regurgitation-Insufficiency(Table 3)

Incidence of at least moderate regurgitation was $6.3 \%$ as assessed by echocardiography in standardised methodology[25].

\section{Discussion}

Quality control in surgery motivates to good operative outcomes [21] but also to long-term results, particularly in surgery for congenital heart disease. We have sometimes seen a 'euphoric' description of operative results but disappointing long-term outcome.

A dissent on the performance of the Contegra is noted: The titles of three of the largest series $[1,2,20]$ were contradictory: direct unequivocal negative message in the first [that was debated strongly in discussion by the audience [1] and enthusiasm in the other two $[2,20]$. Meyns [1] had apparently stopped utilizing Contegra! The difference in opinions may be partially explained by the heterogeneity of the series, as expected from an intervention applicable to premature neonates as well as adults for a constellation of indications.

The experience of Meyns is isolated and rather baffling! If it is excluded, the results are encouraging overall but the follow-up is short. The reason for the high incidence of distal stenosis in Meyns' group remains obscure although the non-use of aspirin may contribute.

The few data on pressure differences are exemplary for the limited data available for all prostheses in vivo. We have to insist that the ubiquitous term 'pressure gradient' is inaccurate when measured in units of pressure and was perceived as pressure difference [24].

The definition of graft stenosis is extremely varying (especially if taken into account the large number of young children where low gradient has a completely different significance than in an adult): higher stenosis rate has been shown in smaller- size patients and conduits.

Echocardiography for estimation of pressure difference is the most common technique since it is easy to apply and relatively of low cost. However, having a large number of complex defects, the question of specificity and sensitivity is important.

Having a relative low number of patient-years of followup could reflect a high mid-term mortality or incomplete follow-up data dies.

A contentious issue is that of post discharge aspirin [[1], see pages 838-40]. (Table 2). Out of the present data, a conclusive answer to whether aspirin prevents graft thrombosis and stenosis is rather difficult. A definitive conclusion would require a randomised prospective trial in order to avoid confounding biases. The feasibility and the ethics of such a study are however also debatable, in the light of the experience of Tiete [4]. It appears reasonable to 'aspirinise' the recipients of Contegra in the absence of contraindications given the known prophylactic value of aspirin in small conduits as coronary bypass.

The choice of the internal diameter of conduit is related to the anatomy and size of the patient (table 4). Most surgeons agree that the largest possible diameter conduit should be utilised. It is impressive that the incidence of stenosis in the smallest $12 \mathrm{~mm}$ conduit was $83.3 \%$ in one trial with diligent follow-up of two years[1]. Interrupted suture line could be considered as a potential solution to 
Table 2: Contegra ${ }^{\mathrm{TM}}$ 1999-2007, follow-up pressure difference and anticoagulation strategy, re-interventions in detail

\begin{tabular}{|c|c|c|c|c|c|c|c|}
\hline reference & $\mathrm{N}$ & peak $\Delta \mathrm{P}$ in $\mathrm{mmHg}$ & mean $\Delta \mathrm{P}$ in $\mathrm{mmHg}$ & Anticoagulation strategy & Percutaneous & Surgical & Total Reinterventions \\
\hline$[1]$ & 55 & unknown & unknown & nil & 17 & 5 & 22 \\
\hline [2] & 67 & 17 & 8 & aspirin for 6 months & 2 & 1 & 3 \\
\hline [3] & 100 & 18 & unknown & nil & 0 & 4 & 4 \\
\hline$[4]$ & 29 & unknown & unknown & $\begin{array}{l}\text { Aspirin until weighing 5-6 } \\
\mathrm{kg}\end{array}$ & 2 & 1 & 3 \\
\hline$[5]$ & 20 & unknown & $13 \pm 4.8$ & Heparinisation and aspirin & 0 & 0 & 0 \\
\hline [6] & 67 & unknown & 11 & nil & 0 & 1 & 1 \\
\hline [7] & 30 & unknown & & nil & 0 & 2 & 2 \\
\hline [8] & 15 & & $11.1 \pm 4.5$ & nil & 0 & 0 & 0 \\
\hline$[9]$ & 6 & 8.5 & $24.5 \pm 13.1$ & aspirin for 3 months max & 0 & 5 & 5 \\
\hline$[10]$ & 40 & $\begin{array}{l}\text { 'increased' in 2- unknown } \\
\text { otherwise }\end{array}$ & & nil & 0 & 3 & 3 \\
\hline$[\mathrm{II}]$ & 38 & unknown & & nil & 0 & 0 & 0 \\
\hline$[12]$ & 12 & unknown & $12.9 \pm 12.3$ & nil & 6 & 3 & 9 \\
\hline$[17]$ & 60 & unknown & & aspirin for 6 months & 6 & 1 & 7 \\
\hline$[21]$ & 62 & unknown & 14 & aspirin for 3 months & 0 & 0 & 0 \\
\hline$[18]$ & 76 & unknown & & aspirin & 4 & 0 & 4 \\
\hline \multirow[t]{2}{*}[22]{} & 78 & 23 & unknown & Heparinisation and aspirin & 19 & 2 & 21 \\
\hline & & & & & 56 & 28 & 84 \\
\hline
\end{tabular}

$\mathrm{N}$ : number of patients followed-up

$\Delta \mathrm{P}$ : Pressure Difference, commonly reported as 'gradient'

$\mathrm{Hg}:$ Mercury

PA: pulmonary artery(-ies) 
Table 3: Contegra ${ }^{\mathrm{TM}}$ 1999-2007: postoperative moderate or severe regurgitation/insufficiency in conduit

\begin{tabular}{|c|c|c|c|}
\hline \multirow[t]{2}{*}{ Reference Number } & \multicolumn{3}{|c|}{ Degree Of Regurgitation/Insufficiency } \\
\hline & III(moderate) & III-IV(moderate to severe) & IV (severe) \\
\hline 1 & 0 & 9 & \\
\hline 2 & & 0 & \\
\hline 4 & 1 & 0 & \\
\hline 5 & & 0 & \\
\hline 6 & & 0 & \\
\hline 8 & & 0 & \\
\hline 10 & & 0 & \\
\hline 11 & & 0 & \\
\hline 7 & & 0 & 3 \\
\hline 12 & & 0 & \\
\hline 17 & & 13 & 3 \\
\hline 21 & & 0 & \\
\hline 20 & & 0 & \\
\hline 21 & & 12 & \\
\hline 22 & & 2 & 2 \\
\hline
\end{tabular}

the distal anastomotic stenosis but is obviously upon to surgeon's preference to apply this technique due to increased risk of bleeding.

Complications were also commoner in double outlet right ventricle and pulmonary atresia, possible because of variable run-off in distal pulmonary vasculature. The excellent results reported on a series of 20 Ross procedures [5], where the run-off at the normal pulmonary vessels is assumed universally good.

\section{Conclusion}

A dissent on the performance of the Contegra is noted: This lack of consensus regarding the best conduit for RVOT reconstruction reflects the fact that no "perfect" solution is available.
It is important to formulate an evidence- base opinion on the available technologies and we hope that our review will address this.

\section{Limitations of the study}

Although every effort was made to extract data that can be pooled and tabulated, the heterogeneity of demographics, casemix and reporting studies performed in different institutions, with different methodologies, populations and time frames was considered an obstacle in inferential statistics; therefore we report descriptive statistics. Comparison between the groups was difficult, especially as data on conduit sizes were missing from the largest series in particular.

We understand that the heterogeneity data may be interpreted in a number of ways equally valid to the one the authors chose here. 
Table 4: Contegra ${ }^{\text {TM }}$ 1999-2007: median size of conduit and follow-up

\begin{tabular}{|c|c|c|c|}
\hline median size $\mathrm{mm}$ & stenosis at follow-up & reintervention or reoperation for conduit failure at follow-up & regurgitation at follow-up \\
\hline 20 & $49 \% \pm 8$ (28 months) & $41 \%(22.7 \pm 10$ months $)$ & $16 \%(22.7 \pm 10$ months $)$ \\
\hline 20 & unknown & $10.4 \%(26.4$ months $)$ & $0 \%(26.4$ months $)$ \\
\hline 14 & & $10(1.1 \pm 1.1$ years $)$ & \\
\hline 14 & & $11.6 \%(1$ year $)$ & $3.4 \%(10.2 \pm 6.4$ months $)$ \\
\hline 22 & $0(13.8 \pm 9.1$ months $)$ & $0(13.8 \pm 9.1$ months $)$ & $0(13.8 \pm 9.1$ months $)$ \\
\hline unknown & $3 \%(10 \pm 2.8$ months $)$ & $3 \%(10 \pm 2.8$ months $)$ & \\
\hline 14 & $12.5 \%$ (3 months) & $12.5 \%(4.3 \pm 2$ months $)$ & $12.5 \%$ (3 months) \\
\hline unknown & & $6.3 \%(\mid 8.5 \pm 6.9$ months $)$ & $0 \%(\mid 8.5 \pm 6.9$ months $)$ \\
\hline unknown & & $0 \%(4 \pm 2.7$ months $)$ & \\
\hline 16 & unknown & unknown & unknown \\
\hline 16 & $15.8 \%(18 \pm 5$ months $)$ & $13.1 \%(18 \pm 5$ months $)$ & unknown \\
\hline 16 & 0 (8.08 months) & unknown & $8.3 \%(8.08$ months $)$ \\
\hline 14 & II.7\%(14 months) & $34 \%$ (38 months) & $26.7 \%(14$ months $)$ \\
\hline \multicolumn{4}{|l|}{ unknown } \\
\hline 16 & $18 \%(3$ years $)$ & $6.9 \%(3$ years) & $36 \%(3$ years $)$ \\
\hline unknown & & $29.5 \%(4$ years $)$ & $16.5 \%(4$ years $)$ \\
\hline unknown & $0 \%(28.1 \pm 17.1$ months $)$ & $0 \%(28.1 \pm 17.1$ months $)$ & $0 \%(28.1 \pm 17.1$ months $)$ \\
\hline
\end{tabular}

\section{Competing interests}

The authors declare that they have no competing interests. $\mathrm{AP}$ has inserted the Contegra and managed patients with previous Contegra insertion.

\section{Authors' contributions}

AP drafted the first manuscript; TA corrected and coauthored the final manuscript.

\section{References}

I. Meyns B, van Garsse L, Boshoff D, Eyskens B, Mertens L, Gewillig M, Fieuws S, Verbeken E, Daenen W: The Contegra conduit in the right ventricular outflow tract induces supravalvular stenosis. J Thorac Cardiovasc Surg 2004, I 28:834-40.

2. Corno AF, Qanadli SD, Sekarski N, Artemisia S, Hurni M, Tozzi P, von Segesser LK: Bovine valved xenograft in pulmonary position: medium-term follow-up with excellent haemodynamic and freedom from calcification. Ann Thorac Surg 2004, 78: 1382-8.

3. Breymann T, Boethig D, Goerg R, Thies WR: The Contegra bovine valved jugular vein conduit for paediatric RVOT reconstruc- tion: 4 years experience with 108 patients. J Card Surg 2004, 19:426-3I.

4. Tiete AR, Sachweh JS, Roemer U, Kozlik-Feldmann R, Reichart B, Daebritz SH: Right ventricular outflow tract reconstruction with the Contegra bovine jugular vein conduit: a word of caution. Ann Thorac Surg 2004, 77:2151-6.

5. Purohit M, Kitchiner D, Pozzi M: Contegra bovine jugular vein right ventricle to pulmonary artery conduit in Ross procedure. Ann Thorac Surg 2004, 77: 1707-10.

6. Kadner A, Dave H, Stallmach T, Turina M, Prêtre R: Formation of a stenotic fibrotic membrane at the distal anastomosis of bovine jugular vein grafts (Contegra) after right ventricular outflow tract reconstruction. J Thorac Cardiovasc Surg 2004, 127:285-6.

7. Boudjemline $Y$, Bonnet $D$, Massih TA, Agnoletti $G$, Iserin $F$, Jaubert $F$ Sidi $D$, Vouhé $P$ : Use of bovine jugular vein to reconstruct the right ventricular outflow tract: early results. J Thorac Cardiovasc Surg 2003, I 26:490-7.

8. Chatzis AC, Giannopoulos NM, Bobos D, Kirvassilis GB, Rammos S, Sarris GE: New xenograft valved conduit (Contegra) for right ventricular outflow tract reconstruction. Heart Surg Forum 2003, 6:396-8. 
9. Erek E, Yalcinbas YK, Salihoglu E, Ozturk N, Arat S, Sarioglu A, Samanli UB, Sarioglu T: Fate of stentless bioprostheses on right side of the heart. Asian Cardiovasc Thorac Ann 2003, I I:58-62.

10. Bove T, Demanet H, Wauthy P, Goldstein JP, Dessy H, Viart P, Deville $A$, Deuvaert FE: Early results of valved bovine jugular vein conduit versus bicuspid homograft for right ventricular outflow tract reconstruction. Ann Thorac Surg 2002, 74:536-4I.

II. Gober V, Berdat P, Pavlovic M, Pfammatter JP, Carrel T: Adverse mid-term outcome following RVOT reconstruction using the Contegra valved bovine jugular vein. Ann Thorac Surg 2005, 79:625-631.

12. Mert M, Cetin G, Turkoglu H, Ozkara A, Akcevin A, Saltik L, Paker T, Gunay I: Early results of valved bovine jugular vein conduit for right ventricular outflow tract reconstruction. Int J Artif Organs 2005, 28:25I-5.

13. Corno AF, Hurni M, Griffin H, Galal OM, Payot M, Sekarski N, Tozzi $P$, von Segesser LK: Bovine jugular vein as right ventricle-topulmonary artery valved conduit. J Heart Valve Dis 2002, I I:242-7.

14. Boethig D, Thies WR, Hecker $H$, Breymann T: Mid term course after pediatric right ventricular outflow tract reconstruction: a comparison of homografts, porcine xenografts and Contegras. Eur J Cardiothorac Surg 2005, 27:58-66.

15. Breymann T, Thies WR, Boethig D, Goerg R, Blanz U, Koerfer R: Bovine valved venous xenografts for RVOT reconstruction: results after 7 I implantations. Eur J Cardiothorac Surg 2002, 21:703-10.

16. Dave H, Kadner A, Bauersfeld U, Berger F, Turina M, Pretre R: Early results of using the bovine jugular vein for right ventricular outflow reconstruction during the Ross procedure. Heart Surg Forum 2003, 6:390-2.

17. Shebani SO, McGuirk S, Baghai M, Stickley J, De Giovanni JV, Bu'lock FA, Barron DJ, Brawn WJ: Right ventricular outflow tract reconstruction using Contegra valved conduit: natural history and conduit performance under pressure. Eur J Cardiothorac Surg 2006, 29:397-405.

18. Brown JW, Ruzmetov M, Rodefeld MD, Vijay P, Darragh RK: Valved bovine jugular vein conduits for right ventricular outflow tract reconstruction in children: an attractive alternative to pulmonary homograft. Ann Thorac Surg 2006, 82:909-16.

19. Carrel T, Berdat P, Pavlovic M, Pfammatter JP: The bovine jugular vein: a totally integrated valved conduit to repair the right ventricular outflow. J Heart Valve Dis 2002, I I:552-6.

20. Morales DL, Braud BE, Gunter KS, Carberry KE, Arrington KA, Heinle JS, McKenzie ED, Fraser CD Jr: Encouraging results for the Contegra conduit in the problematic right ventricle-to-pulmonary artery connection. J Thorac Cardiovasc Surg 2006, |32:665-7|.

21. Rastan AJ, Walther T, Daehnert I, Hambsch J, Mohr FW, Janousek J, Kostelka M: Bovine jugular vein conduit for right ventricular outflow tract reconstruction: evaluation of risk factors for mid-term outcome. Ann Thorac Surg 2006, 82: I 308-15.

22. Chiappini B, Barrea C, Rubay J: Right Ventricular Outflow Tract Reconstruction With Contegra Monocuspid Transannular Patch in Tetralogy of Fallot. Ann Thorac Surg 2007, 83: I85-I87.

23. Guidelines for reporting morbidity and mortality after cardiac valvular operations. Ann Thorac Surg 1988, 46:257-259.

24. Protopapas AD: Pressure gradient in hemodynamics: Is it measured in units of pressure. J Thorac Cardiovasc Surg 2005, 130:952.

25. Zoghbi WA, Enriquez-Sarano M, Foster E, Grayburn PA, Kraft CD, Levine RA, Nihoyannopoulos P, Otto CM, Quinones MA, Rakowski $H$, Stewart WJ, Waggoner A, Weissman NJ, American Society of Echocardiography: Recommendations for evaluation of the severity of native valvular regurgitation with two-dimensional and Doppler echocardiography. J Am Soc Echocardiogr 2003, 16:777-802.

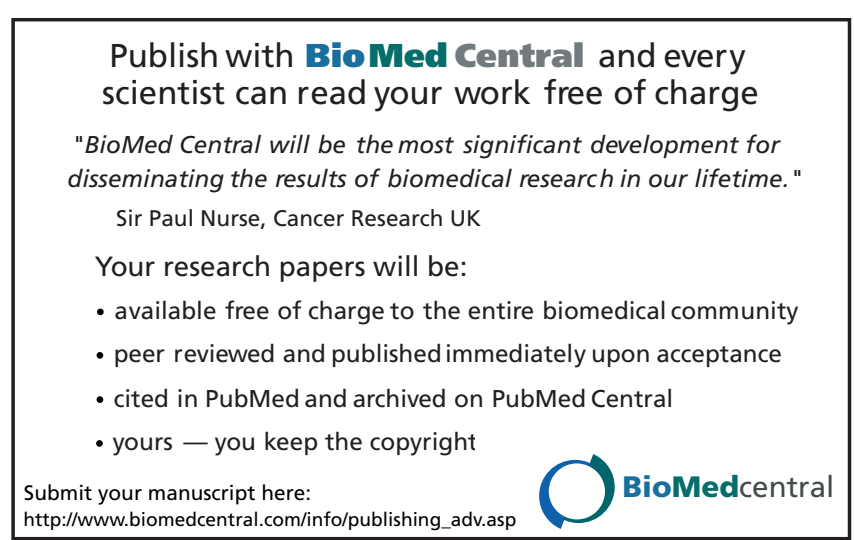

